THE SHAKESPEAREAN METAPHOR 
By the same author

The Art of John Webster

Shakespeare's Comedies : Explorations in Form

On Directing Shakespeare: Interviews with Contemporary Directors 


\title{
THE SHAKESPEAREAN METAPHOR
}

Studies in Language and Form

\author{
Ralph Berry
}

Professor of English

York University, Ontario

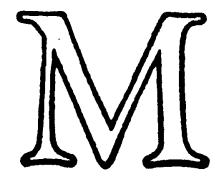


(C) Ralph Berry 1978

Softcover reprint of the hardcover 1st edition 1978

All rights reserved. No part of this publication may be reproduced or transmitted, in any form or by any means, without permission

First edition 1978 Reprinted 1980

Published by THE MACMILLAN PRESS LTD London and Basingstoke Associated companies in Delhi Dublin Hong Kong Johannesburg Lagos Melbourne New York Singapore Tokyo

\section{British Library Cataloguing in Publication Data}

\section{Berry, Ralph}

The Shakespearean metaphor

1. Shakespeare, William-Criticism and interpretation 2. Metaphor

I. Title

822.3'3 PR2997.M/

ISBN 978-1-349-03565-6 ISBN 978-1-349-03563-2 (eBook)

DOI 10.1007/978-1-349-03563-2

This book is sold subject to the standard conditions of the Net Book Agreement 
TO MY FATHER AND MOTHER 


\section{Contents}

Acknowledgements $\quad$ xi

Introduction 1

1 Richard III : Player and King 9

2 King John: Some Bastards Too 26

3 Romeo and Juliet: The Sonnet-World of Verona 37

4 Henry $V:$ The Reason Why 48

5 'To say one' : An essay on Hamlet 61

6 Troilus and Cressida : Tempus edax rerum 74

7 Sexual Imagery in Coriolanus $\quad 88$

8 The Tempest 101

$\begin{array}{ll}\text { Notes } & 117\end{array}$

$\begin{array}{ll}\text { Index } & 127\end{array}$ 


\section{Acknowledgements}

The chapter on Hamlet first appeared in Shakespeare Survey 28 (1975). That on Coriolanus was originally published (in a slightly different form) in Studies in English Literature 1500-1900 (1973), to whose Editor I am indebted for permission to reprint. I wish also to thank the University of Manitoba, for a grant towards secretarial assistance in the preparation of this book.

R.B. 